\title{
Topsy-Turvy and Other Carnivalesque Aspects in Coriolanus
}

\author{
By John Maune*
}

\begin{abstract}
Shakespeare's late tragedy Coriolanus seems to defy definition, having been categorized in a variety of ways from historical tragedy to satirical tragedy to comedy, to name a few. Such a wide spectrum of labels is true too for the play's eponymous character who is seen by many as haughty and proud in the extreme, immature, virtuous, and even lovable. That the tragic hero Coriolanus undergoes extreme topsy-turvy fluctuations at a break-neck pace is a given. Though the play is lacking in laughter-subtle humor is present-it is rife with many poignant examples that illustrate Bakhtin's concept of carnivalistic literary modes. This paper will discuss such extreme carnivalesque transformations, particularly the main character's topsy-turvy fluctuations in name, status, loyalty, and sexuality, as well as his own position relating to the scheme of Bakhtin's carnivalesque concepts.
\end{abstract}

Keywords: Bakhtin, Carnivalesque, Coriolanus, Topsy-Turvy.

\section{Introduction}

Shakespeare's late tragedy Coriolanus is a play that, like the protagonist, seems linear or simplistic, and brutally devoid of redeeming features. However, for all its lack of subtlety, it is a problematic play that, again like the protagonist, defies definition. Swinburne (1880) wrote "a more perfect piece of man's work was never done in all the world than this tragedy", T. S. Elliot (1983) said it was "Shakespeare's most assured artistic success", and the actor Henry Irving (Winter, 1916, p.213) said it was "not worth a damn". Dryden commented that "something in the very Tragedy of Coriolanus, as written by Shakespeare, that is truly great and truly Roman" (i.e., a history play, Dennis 1943). Shaw (1903) called Coriolanus "the greatest of Shakespeare's comedies", Campbell (1971) said it was "perhaps the most successful of Shakespeare's satiric plays, Hellpern (2005) said it could be black comedy, and for Burke (1966) it was a grotesque tragedy. Often performed extensively edited, Coriolanus has been used to mitigate or incite political furor supporting any extreme: Tories, Whigs, Hitler, and Marx's proletariat (Curry, 2010); thus Coleridge thought the politics of the play impartial or for Ripley indeterminate (Ripley, 1998). It is a pity that we will never know how Polonius would have categorized the play.

The play's eponymous character is most often said by critics to be a proud patrician snob lacking in all graces, save military prowess; Lewis (1927) thought "Coriolanus has absolutely no good attribute except physical courage, which he shares with most men and many animals", and was seen by Palmer

\footnotetext{
${ }^{*}$ Professor, Hokusei Gakuen University, Japan.
} 
(1961) as "the splendid oaf who has never come to maturity" and "a proud man who assumes the right to despise persons of a lesser breed".

Two more actors who played Coriolanus, gave their voices. Olivier thought him "a very straightforward, reactionary son of a so-and-so" whose "thoughts are not deep" and "he is a patrician first and foremost, and that his pride is of the nature that he is too proud even to accept praise" (Cook 1983). Ralph Fiennes, who later went on to produce, direct, and star in a movie version of Coriolanus, said, "But I love the anger in it. And he has this aspiration to unbending purity. It can be repellent and fascist, but it's also... he's trying to be something distilled" (Curry, 2010, p. 39). Similarly, Knight (1954) also saw his aristocratic haughtiness and pride, but virtue too: "Each line reflects the whole play, where Coriolanus strides gigantic, thunderously reverberating his aristocracy above the multitude", and "Grim as he is in his warring and pride, we must observe, too, his essential virtue". Bradley (1905) was even more forgiving, "the pride and self-will of Coriolanus, though terrible in bulk, are scarcely so in quality; there is nothing base in them, and the huge creature whom they destroy is a noble, even a lovable, being".

The carnivalesque is Mikhail Bakhtin's concept where the ethos of carnivals in Medieval Europe became part of literary conventions. He discusses these concepts in Rabelais and His World (Bakhtin, 1984), and somewhat in other woks. However, his writings were at times vague, contradictory, or even simplistic, so there is no consensus upon exactly what constitutes carnivalesque, though some core concepts would be accepted by all. One central theme is the topsy-turvy or extreme reversals in statue, behavior, social mores, and even life/death itself, to name but a few. Other core elements include portrayals of the grotesque, and forbidden laughter (e.g., in religious or authoritative contexts), relating both to the corporeal.

Bakhtin said that Shakespeare used carnival imagery (Bakhtin, 1984, p. 11) and that "Shakespeare took advantage of and included in his works immense treasures of potential meaning that could not be fully revealed or recognized in his epoch" (Bakhtin, 1986), which sounds like Bardolatrylauding the universal in Shakespeare. Shakespeare's writings, and in no small part Coriolanus, presage, and most likely influenced, Bakhtin. Burke (1966) used the term grotesque tragedy and Goddard (1960) grotesque language, but both before Bakhtin's concepts were popularized in the west. Maurice Hunt (2004) writes that Coriol-anus alludes to scatological lower body imagery in the play. Extreme reversals abound throughout Coriolanus, that Burke (1966) referred to with the Aristotelian word peripety and discussed briefly (see also Parker, 1993, that is concerned with reversals in Love's Labor's Lost, not Coriolanus). There have been at least two papers on Bakhtinian concepts in Coriolanus (Benson, 1999; Beigi \& Abbasi, 2014), but little of specific carnivalesque topsy-turvy reversals on which, in respect to the title character Coriolanus, this paper will mainly concentrate. 


\section{Discussion}

The play opens with commoners, upset over the lack of food, rioting which is characteristic of social upheavals or transitions in Bakhtin's carnival, which Holquist asserts "is revolution itself" (Bakhtin, 1984, p. xviii). Marcius's first words are grotesque and used to disparage and dispel the rioters (Coriolanus quotes from Shakespeare, 1900).

\subsubsection{3-155}

Marcius - Thanks. What's the matter, you dissentious rogues, That, rubbing the poor itch of your opinion, Make yourselves scabs?

His supreme power over the people is pronounced. Following this, he regretfully relates how the rabble (i.e., commoners or people) are to be given representation in government-tribunes. It is akin to a peasant being crowned king during carnival, and for Marcius, such upheavals to the status quo, a major carnivalesque theme, can only lead to trouble. While he is disparaging the commoners, a messenger brings news that war is afoot. However, following the contempt he showed for the rebelling citizens, he gives high praise for his enemy, the Volscian general, Aufidius, who is intent on the destruction of Rome.

\subsubsection{8-222}

Marcius -They have a leader,

Tullus Aufidius, that will put you to 't.

I sin in envying his nobility,

And were I any thing but what I am,

I would wish me only he.

In the opening scene already, a riot was staged and subdued, and a war begun. Marcius was just defending the city from its own citizens, and next will defend it against a foreign power. Such carnivalesque topsy-turvy fluctuations will continue unabated "like a streamlined missile" (Fiennes in Curry, 2010, p. 41) until the play's conclusion.

The war starts. Marcius and his troops are beaten back by the Volsces who are defending the city Corioli. Marcius then castigates his soldiers severely for the defeat. While ranting at his men, he notices that the Volsces are entering Corioli via the open gate, thus he urges, sans haranguing, his men to do as he does and attack. However, the men, tired from the battle they just lost and the tongue lashing from their commander, watch disinterestedly as Marcius enters the city. The gate shuts him in alone-presumed dead by all.

\subsubsection{6-57}

First Soldier - See, they have shut him in.

All - To the pot, I warrant him. 
Rome's fallen hero is lamented with grand praise only for the impromptu eulogy to be interrupted by a bleeding fighting Marcius who is expelled from Corioli like a bloody baby spewed forth at birth. "Like in Dionysic rituals, the celebration of the god is followed by tearing him apart, and after his rebirth new celebration ensues" (Pikli, 2001). During carnival, people disguised their identities with masks which freed them from the usual societal constraints, but within limits meted out by the authorities. Bakhtin placed great meaning on the mask relating it to reincarnation, metamorphoses, and violation of natural boundaries where reality and image blurred as in ancient rituals (Bakhtin, 1984, p. 40). Marcius was masked in his own and his enemies' blood such that he was unrecognizable. He entered the city and died, only to be cast out alive, reborn, reincarnated - the resurrection of Marcius - in the ultimate reversal and misalliance - the joining of birth and death. His rebirth is later made doubly so when he receives his honorific Coriolanus for a new identity, becoming the carnival metaphor incarnate.

Marcius then gives a rousing speech channeling Henry V. Shortly before, his belittled men sullenly watched him enter Corioli to certain death. Now, the reborn Marcius excites them to a fever pitch. It is shown here that he could be eloquent and enlist people to his cause, but only if he truly believed in the cause; he is no actor.

\subsubsection{5-95}

Marcius - Those are they

That most are willing. If any such be here-

As it were sin to doubt - that love this painting

Wherein you see me smear'd; if any fear

Lesser his person than an ill report;

If any think brave death outweighs bad life

And that his country's dearer than himself;

Let him alone, or so many so minded,

Wave thus, to express his disposition,

And follow Marcius.

[They all shout and wave their swords, take him up in

their arms, and cast up their caps]

$\mathrm{O}$, me alone! make you a sword of me?

Then Marcius seeks out and meets his arch enemy Aufidius, and before they engage in combat he expresses his hatred.

\subsection{1-2}

Marcius - I'll fight with none but thee; for I do hate thee

Worse than a promise-breaker.

The most disparaging remark for Marcius is to label Aufidius a promisebreaker. This sounds more like a schoolboy than a proud warrior, but, for Marcius at least, it is the vilest invective; your word impacts your honour. 
Aufidius is nearly beaten, and, much against his will, some compatriots forcibly aid his escape.

Marcius's valiant deeds are praised, and he is given one tenth of the spoils, a princely sum, but he refuses. The enemy of the people, now, for the time being at least, revered as a hero, is forcibly given the appellation Coriolanus-a carnivalesque reversal of semiotic import; his achievements will be coded in his name for all to witness.

\subsubsection{0-67}

Cominius - Too modest are you;

More cruel to your good report than grateful

To us that give you truly: by your patience,

If 'gainst yourself you be incensed, we'll put you,

Like one that means his proper harm, in manacles,

Then reason safely with you. Therefore, be it known,

As to us, to all the world, that Caius Marcius

Wears this war's garland: in token of the which,

My noble steed, known to the camp, I give him,

With all his trim belonging; and from this time,

For what he did before Corioli, call him,

With all the applause and clamour of the host,

CAIUS MARCIUS CORIOLANUS! Bear

The addition nobly ever!

Before Coriolanus can wash his sanguine disguise, he remembers himself.

\subsubsection{8-90}

Coriolanus -The gods begin to mock me. I, that now

Refused most princely gifts, am bound to beg

Of my lord general.

He then begs for the freedom of a poor Corioli man, now a prisoner, in whose house Marcius, now Coriolanus, had stayed at in times past. Cominius readily agrees to set him free, and asks for the man's name-Coriolanus in his wearied state has forgotten. Thus the hero goes from refusing extreme wealth to begging, Mars-like war engine killing all in his path to humane altruist suing for clemency for an enemy, a poor one at that, and finally to weary supplicant forgetting the man's name for whose freedom he pleads.

Coriolanus left Rome as the people's enemy, but returns the hero to praise and adulation. However, Bakhtin mentions that early Roman triumphal processions were equal parts in glorification and derision for the hero (Bakhtin, 1984, p. 6). Thus, Coriolanus, the hero, would have been both praised and ridiculed when he entered Rome. This was central to the carnivalesque where the higher classes were put down and the lower classes put on upper class airs. Coriolanus as hero would uniquely experience both extremes and serve, in a sense, as his own fool-again the embodiment of the topsy-turvy. 
After serving valiantly in 17 military campaigns, Coriolanus is nominated for consul. The custom is that Coriolanus must stand meanly dressed in the forum, begging the support of the commoners who freely converse with him viewing his wounds. The old Roman carnival-type ritual is thoroughly carnivalesque.

Before Coriolanus arrives to beg for their support, a group of citizens are discussing their obligations in the custom. They, while shadowing Coriolanus's musings, have misgivings, but feel compelled to adhere to custom.

\subsection{3-12}

Third Citizen - We have power in ourselves to do it, but it is a power that we have no power to do; for if he show us his wounds and tell us his deeds, we are to put our tongues into those wounds and speak for them; so, if he tell us his noble deeds, we must also tell him our noble acceptance of them. Ingratitude is monstrous, and for the multitude to be ingrateful, were to make a monster of the multitude: of the which we being members, should bring ourselves to be monstrous members.

There was power to be gained during carnival, but it was most often transitory as was the apparent freedom, though, as Bakhtin thought, such plays of power and freedom were seeds of revolution. The citizens show that they wear their power only to play their assigned roles; in essence they have no power. The tribunes wield the people's power. The allegorical use of the people's tongues in Coriolanus's wounds is grotesque, or a kind of cunnilingus, or even sacrilegious where the wounds are stigmata. Coriolanus is seemingly a polar opposite to Christ, but he had already risen from the dead. Such unnatural unholy pairings embody the carnivalesque.

\subsubsection{7-161}

Coriolanus - I do beseech you,

Let me o'erleap that custom, for I cannot

Put on the gown, stand naked and entreat them,

For my wounds' sake, to give their suffrage: please you

That I may pass this doing.

\subsubsection{9-170}

Coriolanus - It is apart

That I shall blush in acting,

Everything in the spectacle-wearing the peasant gown, showing his wounds, being civil to the commoners, and even standing for consulinfuriates him, as do all carnivalesque elements. Throughout the play, dramatic 
tension is maintained by his constant immersion in the carnivalesque that is so contrary to his solitary noble, and often pointedly haughty, nature.

Coriolanus approaches, but skirts Bakhtin's concepts here. He subtly mocks, not begs, the commoners, and more significantly, never shows his wounds, yet he secures their voices for his consulship bid. The people do eventually come to realize, or at least have such knowledge implanted in their pliable minds, well after the fact, that they were mocked, which the tribunes use to their advantage.

The marketplace was the "popular sphere" where the equalizing and humanizing aspects of carnival had to be "tolerated and even legalized" (Bakhtin, 1984, p. 9), and the bodily elements in grotesque realism were not to be presented in "a private egoistic form" and "were not in the biological individual, not in the bourgeois ego, but in the people, a people who are continually growing and renewed" (Bakhtin, 1984, p. 19). Coriolanus is loath to show or discuss his wounds, but the commoners, tribunes, Volumnia, and Menenius all do so in overly grotesque, intimate detail; the wounds are to them not private, but for all the people. The wounds ooze semiotic details including grotesque carnivalesque tropes.

One vital carnivalesque element lacking, not absent though, in the play is laughter. This gown of humility scene does have some satirical humor in the way Coriolanus is fighting his own desire to rebuke the commoners for all their shortcomings while trying to be nice as advised by Volumnia and Menenius. However, there is none of the folksy liberating laughter Bakhtin believes in. Bakhtin's sometimes conflicting and simplistic views and interpretations are rightfully questioned especially as many carnivals ended in violence, and due to their seditious dynamics, were often opposed by the authorities (Bernstein, 1983; Stevens, 2007); laughter is hardly the first image that comes to mind when thinking of class struggle and revolution.

When the ordeal is over, he wants to get out of the mean costume-out of the carnivalesque - and become himself again straight away. This is a recurring motif - he does not want to act counterfeit and participate in the carnivalesque world of masks and costumes.

\subsubsection{0-151}

Coriolanus - That I'll straight do; and, knowing myself again,

Repair to the senate-house.

In a tragicomic reversal, the people recant their support and show themselves to be the monstrous ungrateful members they explicitly wanted to avoid; they are manipulated to do so by their tribunes. The tribunes, dizzy with success, and, for appearance's sake, the people, try Coriolanus as a traitor; one goal of all revolutions is to take the power of law out of the hands of the ruling class. The tribunes provoke, with ridiculous ease, Coriolanus to anger with one word - traitor. Coriolanus erupts and spouts invective over the masses. He was a few kind words away from becoming consul, but he would not say even Good morrow to cause the people to give him their voices. 


\subsubsection{0-116}

Coriolanus - I know no further:

Let them pronounce the steep Tarpeian death,

Vagabond exile, raying, pent to linger

But with a grain a day, I would not buy

Their mercy at the price of one fair word;

Nor cheque my courage for what they can give,

To have't with saying 'Good morrow.'

$\mathrm{He}$ is summarily proclaimed banished from Rome by the tribune-lead commoners. The city is in revolt pitting commoner against patrician. This is the first of the play's three great dramatic reversals; Coriolanus is ejected from Rome like a fool at the end of a festival, his mock reign over (Aschenasy, 2007).

Coriolanus is no fool though, and accosts the mob "employing his usual diplomatic balm" (Armen \& Taylor, 1969).

\subsubsection{7-162}

Coriolanus - You common cry of curs! whose breath I hate

As reek o' the rotten fens, whose loves I prize

As the dead carcasses of unburied men

That do corrupt my air, I banish you;

And here remain with your uncertainty!

Let every feeble rumour shake your hearts!

Your enemies, with nodding of their plumes,

Fan you into despair! Have the power still

To banish your defenders; till at length

Your ignorance, which finds not till it feels,

Making not reservation of yourselves,

Still your own foes, deliver you as most

Abated captives to some nation

That won you without blows! Despising,

For you, the city, thus I turn my back:

There is a world elsewhere.

The drastic reversals, oscillations of context and power, led to revolution and a new order with the people's enemy, recently Rome's honoured hero, Coriolanus, banished. The hierarchal reversal removes his status right when he should have been at his most powerful, and this by those who had already sworn their voices to his cause. This is the carnivalesque, but again with no sign of humor, but perhaps ironically some joy-Coriolanus seems happy. $\mathrm{He}$ reacts as one not disempowered, but rather one set free from the restrictions of his supporters who would have had him consul, a swaying politician, a role he did not at all covet; he is empowered. Sanders convincingly argues that "Coriolanus is at the center of contemporary controversy over the legitimacy of theater" (Sanders, 2006); thus the many double entendres and allusions to 
acting. Sanders believes, mistakenly I feel, that Coriolanus professes to shun acting, only to become a "shape-shifting actor" following his banishment. In any case, he banishes his banishers shattering boundaries they might have thought existed, and hurls insults on his sea of peasant judges. It is easy to picture his banishers cowering in fear; the powerful mob is terrified of the one lone dragon. His vitriol perhaps spent, he now despises Rome and turns his back, fearing no reprisal, to go out into his brave, of course, new world.

Before leaving Rome, Coriolanus is not fuming or bubbling anger, but instead is possibly more relaxed and even happier than anytime in the play. He goes out of his way to give solace to his grieving family and friends who are angry about what he has and will have to endure. When saying he will "go alone, like a lonely dragon" (4.1.31-32), this appeals to his solitary-thus antithesis to the carnivalesque-nature.

He finds his way to Antium, where Aufidius, his noble enemy, dwells. He enters the city as the uncharacteristically copious stage notes relate in detail: in mean apparel, disguised, and muffled (i.e., masked). This is where Sanders feels Marcius is morphing into a "shape-shifting actor" (Sanders, 2006), but to saunter into an enemy city, in which he is probably thought of as the devil, would serve no purpose except his death. Incognito he must be, he reflects with some humor, lest wives or boys whose husbands or fathers he killed might slay him in puny battle. This is not entering Trojan horse-like to destroy a city, but to die or serve - "honour and policy, like unsever'd friends" (3.2.54)—placing his hopes and life in his enemies hands. Death must wait for such theatre.

Marcius, his honorific shed in Volscian Antium, enters Aufidius's house, who is hosting a feast. According to Bakhtin, official feasts "sanctioned the existing pattern of things and reinforced it" (Bakhtin, 1984, p. 9), but not this feast. Marcius manhandles some serving men who want to throw him out as he demands to meet the master of the house. Aufidius comes to find the source of the disturbance, but cannot identify Marcius who then unmuffles (i.e., unmasks). Aufidius still cannot identify the dirty pauper in his house and repeatedly asks for his name. Marcius then identifies himself and presents his throat for Aufidius to cut or if not that, then his proffered service to Aufidius and the Volscians - the second of the three great reversals ensues. Marcius had entered the city as a noble man masked and dressed like a peasant in classic carnival style, but by stating his name, he starts a deluge of carnivalesque reversals: Aufidius does not kill his despised enemy Marcius, but is enamored of him and they form a homoerotic misalliance; Aufidius cuts his army in two to give Marcius half. The masked visitor is really an enemy nobleman who is elevated to a Volscian nobleman. And before the first drinks are finished, the official party turns into a carnivalesque feast presided over by a vagabond who is also their arch enemy/newest general/butcher of scores of their citizens; war is begun, and dinner is finished. Antium's citizens should want to tear Marcius apart, but instead they worship him. The Volscians originally did not want to attack Rome, but do after Marcius takes command. The image of a dirty Marcius in tattered clothes being feasted and fawned on by the elite of Antium, is pure carnival. 
The action continues apace. The unlikely allies are finding it easy work taking Roman territory that "do smilingly revolt" (4.6.133). Marcius "fights dragon-like, and does achieve as soon as draw his sword" (4.7.25-26) so that Rome's downfall is imminent.

\subsubsection{4-120}

Cominius - If!

He is their god: he leads them like a thing

Made by some other deity than nature,

That shapes man better; and they follow him,

Against us brats, with no less confidence

Than boys pursuing summer butterflies,

Or butchers killing flies.

Rome is at the mercy of the Roman they banished, leading a foreign force. Cominius visits Marcius - the subordinate is recognized by all as the actual leader with Aufidius relegated to brooding titular commander-interceding on behalf of Rome, but Marcius is unmoved.

\subsubsection{0-16}

Cominius - Yet one time he did call me by my name:

I urged our old acquaintance, and the drops

That we have bled together. Coriolanus

He would not answer to: forbad all names;

He was a kind of nothing, titleless,

Till he had forged himself a name o' the fire

Of burning Rome.

This is the most extreme alteration associated with his oft-changing name-nothingness.

Menenius meets Marcius, but he too is unsuccessful in suing for mercy. The strain in Marcius is apparent as he briefly speaks and gives Menenius, who is like a father, a letter he had prepared at an unknown time before their meeting.

\subsubsection{2-97}

Coriolanus -Mine ears against your suits are stronger than

Your gates against my force. Yet, for I loved thee,

Take this along; I writ it for thy sake

[Gives a letter]

And would have rent it. Another word, Menenius, I will not hear thee speak. This man, Aufidius,

Was my beloved in Rome: yet thou behold'st!

He feels it necessary to point out to Aufidius how unbending he is, even with his beloved father figure. Marcius freely states his love for Menenius, 
hands over a letter written at an unknown prior time for his sake, and then looks to Aufidius for approval. Really? This is most unusual behavior. We are not privy to the contents, but the message is clear; the hero is not as isolated and heartless as played. The facade/mask is cracking; the last of the three great topsy-turvy reversals is imminent.

Just before meeting his wife, child, and mother, Marcius again relates how well he is serving the Volscians. Again this fawning is most out of character, and indicates inner turmoil and doubt which were not evident until approaching Rome.

\subsection{1-4}

Coriolanus - We will before the walls of Rome tomorrow

Set down our host. My partner in this action,

You must report to the Volscian lords, how plainly

I have borne this business.

Just before the final of the three great reversals - the intercession scenethat will prove most mortal for Marcius, he says he will meet no more suitors from Rome. But, his family appears.

\subsubsection{2-23}

Coriolanus - Shall I be tempted to infringe my vow

In the same time 'tis made? I will not.

His wife Virgilia appears with their young son Marcius, Volumnia, and Valeria. His will is almost even spent at the mere sight of her before she utters a single word. Virgilia then speaks a few lines and the final reversal proceeds apace. It is assumed by many that Volumnia's lengthy speeches dissuade her son from finishing his vengeance, but Goddard (1960, pp. 219-220) feels otherwise. More circumspect reading reveals that Virgilia with her mere presence, a few spoken deferential words, and a kiss "Long as my exile, sweet as my revenge!" (5.3.48-49) saved Rome, not Volumnia's long winded harangue.

\subsubsection{9-31}

Coriolanus - What is that curt'sy worth? or those doves' eyes, Which can make gods forsworn? I melt, and am not

Of stronger earth than others.

\subsubsection{4-46}

Coriolanus - Like a dull actor now, I have forgot my part, and I am out, Even to a full disgrace.

Marcius decides not to sack Rome, though its defeat is assured. By his own standards, he is now a disgraced promise breaker, though he accomplished 
far more than his new allies ever imagined. He was singularly focused throughout the play, but no more. His rage was spent as he looked on his wife and child and his harshness melted to mercy and forgiveness. He realizes his life is forfeited, so that his final rebirth/reversal is in essence his death. He will not die on a cross, but his transmogrification with its roots in mercy alludes to his own Gethsemane. Like Christ he knows what is coming, but he bravely soldiers on.

Antium. This time Marcius enters to great fanfare a victorious adored Volscian, though Roman, hero while Aufidius is all but forgotten. But, we all know that cities are topsy-turvy wormholes for Marcius.

\subsubsection{7-62 \\ [Drums and trumpets sound, with great shouts of the People]}

First Conspirator - Your native town you enter'd like a post, And had no welcomes home: but he returns, Splitting the air with noise.

Second Conspirator - And patient fools, Whose children he hath slain, their base throats tear With giving him glory.

However, marginalized, jealous, and proud Aufidius has also written a letter, but his is for the Volscian rulers. His enemy is his enemy again and just as the tribunes had done, Aufidius orchestrates the fall of Marcius. Again getting Marcius incensed is rather easy-a boy of tears. What proceeds is Shakespeare's Roman version of suicide by cop - suicide by mob. Marcius fans the assembled people's easily ignited smouldering embers of hate-he is the one usually being so provoked-using his well-oiled oratorical diatribe skills.

\subsubsection{0-135}

Coriolanus - Cut me to pieces, Volsces; men and lads,

Stain all your edges on me. Boy! false hound!

If you have writ your annals true, 'tis there,

That, like an eagle in a dove-cote, I

Flutter'd your Volscians in Corioli:

Alone I did it. Boy!

\subsubsection{0-143}

All Conspirators - Let him die for't.

All The People - 'Tear him to pieces.' 'Do it presently.' 'He kill'd my son.' 'My daughter.' 'He killed my cousin

Marcus.' 'He killed my father.'

He instigates his own suicide and is content to let himself be hacked to death, a betrayed god willingly dying so others might live. After killing him, 
Aufidius repents the deed in the play's final reversal stating, recalling Hamlet, "he shall have a noble memory" (5.6.181).

\section{Conclusions}

His tumultuous entrances, reversals, and exits were carnivalesque: Marcius in Rome, from hero to being banished, Corioli, from being dead to being reborn, and Antium, first as disguised loathed enemy to noble general, and finally as a dragon-like triumphant war god Mars to corpse. "The seasonal festivities usually ended with the expulsion of a comic scapegoat, a ritual whereby, as Frye explains, society purges itself of the spirit of chaos that has temporarily seized it" (Aschenasy, 2007).

In Coriolanus, Shakespeare created a carnivalesque political drama where volte-face is the norm for the main character who confronts preposterous exigencies while not swaying from what he is-Marcius-alone. Bakhtin thought that "complete liberty is possible only in the completely fearless world" (Bakhtin, 1984, p. 41) which can be seen as the eventual goal of revolutions and the carnivalesque. Only a few scenes raise doubts on his fearlessness: he is loath to show his wounds to the commoners, some interactions with his mother, and first entering Antium. They are also the only palpably humorous scenes; Marcius/Mars cowering to peasants or the women and boys of Antium - or even Volumnia - is preposterous.

The other characters sway with the times and show their Machiavellian natures, time and time again - both patrician and commoner-but not Marcius. His mother Volumnia is especially repellent in how she does not practice what she preached to her own son. Goddard feels Marcius's adult life was drawn from the lessons drilled into him by his overbearing mother, and not by his own true nature (Goddard, 1960). Her lessons molded him to be free of fear which he demonstrated again and again with his solitary valour: alone, he defied a riotous mob, alone attacked an enemy city, and entered his mortal enemies' house alone. Marcius lived free of fear, thus in a quasi-carnivalesque state, though it seems freedom of fear was the only carnivalesque aspect that appealed to him. However, Marcius can be said to have one fear-being false to his nature (3.2.17) or swaying in his actions (2.1.210). The intercession scene raises questions about exactly what was his nature, though suing for the old man's freedom in Corioli gave a prior indication. Marcius's most fearless act might have been sparing Rome, knowing it was most mortal to him. There is a world elsewhere (3.3.162).

\section{References}

Armen, M., 1969. The Cloud Miners. Television program, Los Angeles: Paramount Television. Available from: ttp://www.chakoteya.net/StarTrek/74.htm. 
Aschenasy, N., 2007. Reading Ruth through a Bakhtinian Lens: The Carnivalesque in a Biblical Tale. Journal of Biblical Literature, 126(3), pp. 437-453. Available from: http://languages.uconn.edu/faculty/CVs/2014CVs/CVAschkenasy.doc.

Bakhtin, M., 1984. Rabelais and His World. Translated by: H. Iswolsky. Bloomington, Indiana: Indiana University Press.

Bakhtin, M., 1986. Speech Genres and Other Late Essays. Translated by: V. McGee. In: C. Emerson \& M. Holquist, eds. Austin, Texas: University of Texas Press, p. 5.

Beigi, R., \& Abbasi, P., 2014. "Coriolanus": Celebrating a Bakhtinian Anarchic Body of Roman Republic. International Letters of Social and Humanistic Sciences, 37, pp. 5-17. Available from: http://www.scipress.com/ILSHS.37.5.

Benson, S., 1999. "Even to the Gates of Rome": Grotesque Bodies and Fragmented Stories in Coriolanus. Comitatus, 30(1), pp. 94-113. Available from: https://escholarship.org/uc/item/32z655v9.

Bernstein, M., 1983. When the Carnival Turns Bitter: Preliminary Reflections upon the Abject Hero. Critical Inquiry, 10(2), pp. 283-305.

Bradley, A., 1905. Shakespearean Tragedy: Lectures on Hamlet, Othello, King Lear, Macbeth. 2nd edn. London, Macmillan, p. 83.

Burke, K., 1966. Coriolanus - and the Delights of Faction. The Hudson Review, 19, pp. 185-202.

Campbell, O. J., 1971. Shakespeare's Satire. 2nd edn. New York: Gordian Press, p. 199.

Cook, J., 1983. Shakespeare's Players. 2nd edn. London: Harrap Limited, p. 94.

Curry, J., 2010. Shakespeare on Stage. London: Nick Hern Books, p. 38.

Elliot, T. S., 1983. The Sacred Wood. 8th edn. London: Methuen, p. 99.

Goddard, H., 1960. The Meaning of Shakespeare, vol. 2. 2nd edn. Chicago: University of Chicago Press, p. 217.

Hellpern, J., 2005. Shakespeare's Least-Loved Play; But This Coriolanus Stands Apart. Observer. $28^{\text {th }}$ February. Available from: htp://observer.com/2005/02/sha kespeares-leastloved-play-but-this-coriolanus-stands-apart/.

Hunt, M., 2004. The Backward Voice of Coriol-anus. Shakespeare Studies, 32, pp. 220-239.

Knight, G., 1954. The imperial theme: further interpretations of Shakespeare's tragedies including the Roman plays. London: Methuen, pp. 160-163.

Lewis, W., 1927. The Lion and the Fox. London: Grant Richards, p. 241.

Palmer, J., 1961. Political Characters of Shakespeare. 6th edn. London, Macmillan, pp. $297 \& 309$.

Parker, P., 1993. Preposterous Reversals: Love's Labor's Lost. Modern Language Quarterly, 54(4), pp. 435-482.

Pikli, N., 2001. The Carnival and Carnivalesque Laughter, Falstaff's Mythical Body. In: The Prism of Laughter. Shakespeare's "very tragical mirth" (Doctoral dissertation), p.6. Available from: https://www.academia.edu/7986846/_The _Carnival_and_Carnivalesque_Laughter_Falstaffs_Mythical_Body_.

Ripley, J., 1998. Coriolanus on Stage in England and America, 1609-1994. Cranbury: Associated University Presses, pp. 56 \& 337.

Sanders, E., 2006. The Body of the Actor in Coriolanus. Shakespeare Quarterly, 57(4), pp. 387-412.

Shaw, B. 1903. Man and Superman. Cambridge, Mass.: The University Press. Available from: http://www.bartleby.com/157/100.html.

Shakespeare, W., 1900. Coriolanus. In: K. Deighton, ed. London: Macmillan. Available from: http://www.shakespeare-online.com/plays/corio_1_2.html. 
Stevens, A., 2007. Carnival and comedy: on Bakhtin's misreading of Boccaccio. Opticon 1826(3), pp.1-5. Available from: http://www.opticon1826.com/articles/ abstract/10.5334/ opt.030707/.

Swinburne, A. C., 1880. A study of Shakespeare. 2nd edn. London: Chatto \& Windus, p.188, Available from: https://ia802606.us.archive.org/21/items/astudyshakespea 02swingoog/astudyshakespea02swingoog.pdf.

Winter, W., 1916. Shakespeare on the Stage (3rd Series). New York. (Reissued Benjamin Blom, 1969). 
